VAS at the baseline were all significantly high in Response (good response+ moderate response) group than No-response group (table 1). Yearly mTSS was 0.60 and rate of structural remission (mTSS $\leq 0.5$ ) was $87 \%$. Rapid radiological progression was not seen even if yearly $\mathrm{mTSS}$ at the baseline was 5.52 . The relation between yearly mTSS and disease duration was shown in Figure $(r=0.33$, $\mathrm{p}=0.029$ ). Adverse $\mathrm{AE}$ were observed such as transaminase elevation, stomatitis and dizziness. All AE was not serious. DAS28-ESR, CRP, ESR and swelling joint were prognostic factors of the group of good and moderate response against no response group.

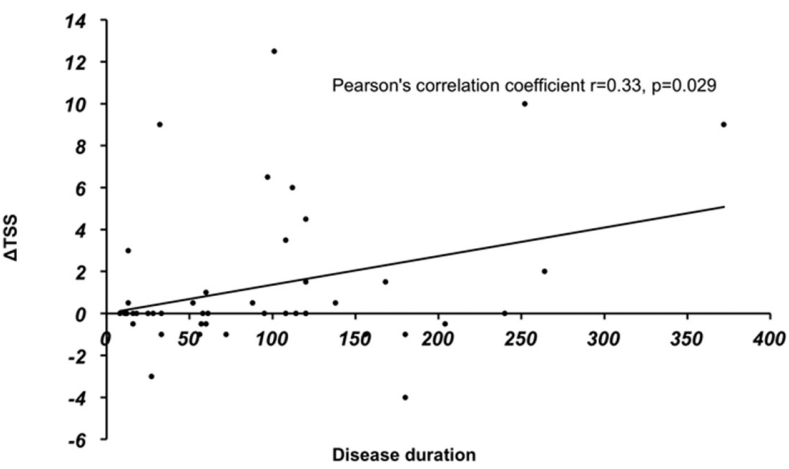

Abstract AB0490 - Figure 1

Conclusions: Adding IGU to csDMARDs with poor response in RA patients is effective, but $A E$ should be considered. Radiographic progression by lguratimod might be inhibited in early phase of RA.

Disclosure of Interest: None declared

DOI: 10.1136/annrheumdis-2018-eular.2834

\section{AB0491 POSSIBLE LINKAGE BETWEEN INTESTINAL BACTERIA COMPOSITION CHANGES AND DISEASE ACTIVITY IN PATIENTS WITH RHEUMATOID ARTHRITIS TREATED WITH NATURAL MILK ANTIBODIES AGAINST ENTERIC BACTERIA AND THEIR TOXINS}

K. Katayama. Orthopedic Surgery, Katayama Orthopedic Rhematology Clinic, Asahikawa, Japan

Background: A growing body of research has indicated potential association between dysbiosis or imbalance of intestinal bacterial flora and RA. Previously, we demonstrated the natural milk antibody preparation containing high levels antibodies against pathogenic enteromicrobes and their toxins seems to be effective in a certain RA subset in an open labelled pilot study $\left(.{ }^{1}\right.$

Objectives: To investigate the effects of natural milk antibodies (Ab) on intestinal bacteria composition, and consequent therapeutic effect on disease activity of RA by multicenter randomised double blind clinical trial (UMIN CTR: 000009492). Methods: Eighty-seven patients with RA with disease activity score of 28 joints with ESR (DAS 28-ESR) values above 3.2 were divided into 3 groups (29 patients each), and treated with $600 \mathrm{mg}$ of $\mathrm{Ab}, 300 \mathrm{mg}$ of Ab plus $10 \mathrm{~g}$ of skim milk (prebiotics), and $20 \mathrm{~g}$ of skim milk alone, respectively, for 12 weeks. The therapeutic effects of milk antibody treatment were determined by DAS28-ESR, swollen joint count (SJC), tender joint count (TJC), and visual analogue score (VAS). The biological effects of milk antibodies were examined by serum and faecal LPS concentration, and faecal bacterial composition changes before and after the treatment. Bacteria composition changes was determined by quantitative PCR of bacterial 16S rRNA.

Results: A significant reduction in DAS28-ESR values from 4.6 to 4.1 was observed at 4th week in Ab $300 \mathrm{mg}$ plus skim milk group (figure 1). Importantly, this effect was lasted through until 12th week $(p<0.01)$, but DAS28-ESR values gradually returned to original levels after discontinuation of the treatment. On the other hand, neither high dose of milk antibody $(600 \mathrm{mg})$ nor $20 \mathrm{~g}$ of skim milk had little effect on DAS28-ESR. Characteristic effect of milk antibody treatment observed in the Ab $300 \mathrm{mg}$ plus skim milk group was the improvement of SJC, TJC, and Pain VAS. No severe adverse events have been observed. Enteric microbe analysis before the treatment indicated lower Bacteroides fragilis (less than $1 / 100$ compared to healthy adults) and higher Staphylococcus aureus population (1000x higher) in patients with RA, indicating a dysbiosis in RA. The DAS28-ESR value reduction in the Ab $300 \mathrm{mg}$ group was associated with an increase in the Lactobacillus population. In contrast, the improvement of Pain VAS was associated with an increase in the $B$. fragilis population. Possible improvement in the intestinal barrier function was assumed by the reduction of serum and faecal LPS concentration ratio in the Ab $300 \mathrm{mg}$ groups.

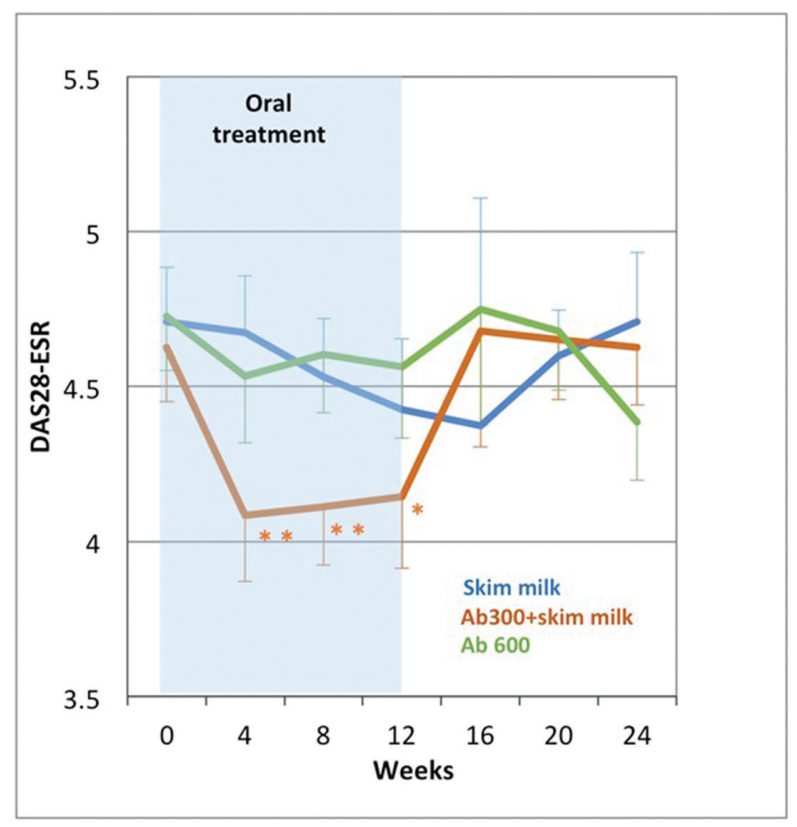

$*: \mathrm{p}<0.05, * *: \mathrm{p}<0.01$ (Paired t-test), Data: mean $\pm S E$

Abstract AB0491 - Figure 1. Therapeutic effect of natural milk antibodies on rheumatoid arthritis

Conclusions: Natural milk antibody treatment modulates the intestinal bacterial composition, and consequently may contribute to improving disease activity of RA.

\section{REFERENCE}

[1] Katayama K, Matsumoto T, Waritani T, Terato K, Shionoya H. Supplemental treatment of rheumatoid arthritis with milk antibodies against enteromic robes and their toxins: result of an open-labelled pilot study. Nutrition $\mathrm{J}$ 2011;10:2

Acknowledgements: The author thanks my colleagues, Drs. H. Shionoya, K Kitamura, S. Suzuki, R. Fukai, T. Okubo, K. Kamiya, T. Sato, T. Abe, S. Uda,K Nishimura, H. Takemori, H. Baba, T. Waritani, K. Terato, and H. Ito for conducting this study.

Disclosure of Interest: None declared

DOI: 10.1136/annrheumdis-2018-eular.2320

\section{AB0492 JAK-INHIBITION WITH PEFICITINIB AND FILGOTINIB IN FIBROBLAST-LIKE SYNOVIOCYTES IN RHEUMATOID ARTHRITIS}

M. Diller $^{1}$, M.-L. Hülser ${ }^{1}$, R. Hasseli ${ }^{1}$, S. Rehart ${ }^{2}$, U. Müller-Ladner ${ }^{1}$, E. Neumann ${ }^{1}$. ${ }^{1}$ Dept. of Rheumatology and Clinical Immunology, Campus Kerckhoff, JustusLiebig-University, Gießen; ${ }^{2}$ Dept. of Orthopaedics and Trauma Surgery, Agaplesion Markus Hospital, Frankfurt, Germany

Background: With the approval of the Janus kinase inhibitors (JAKi) Tofacitinib and Baricitinib for the treatment of rheumatoid arthritis (RA) in the European Union $(E U)$, the opportunities for a successful therapy were extended by a new substance class. Other JAKi like Peficitinib and Filgotinib are currently examined in clinical trials. Peficitinib is a pan-JAKi, whereas the other substances differ clearly in the capability to block the four members of the Janus kinase family. It is unclear if the new substances offer an additional benefit in RA treatment in comparison to the approved JAKi.

Objectives: This study characterised the effect of the different JAKi on inflammatory response of activated fibroblast-like synoviocytes from patients with RA (RAFLS).

Methods: RA-FLS were isolated from synovial tissue of patients with RA undergoing joint replacement surgery. The cells were pretreated for 2 hour with different concentrations of JAKi or vehicle control and then stimulated with IL1- $\beta$ (10 or $20 \mathrm{ng} / \mathrm{ml})$ or Oncostatin M (OSM, $100 \mathrm{ng} / \mathrm{ml})$. After the indicated time (1724 hour), the supernatants were collected and the concentrations of IL-6 and MMP-3 were measured by ELISA. An assay combining the measurement of cell viability, cytotoxicity and apoptosis was performed to exclude effects of JAKi caused by cell toxicity. 